\title{
A new normal for hypertension medicine with coronavirus disease- 2019 (COVID-19): proposal from the president of the Japanese Society of Hypertension
}

\author{
Hiroshi Itoh ${ }^{1}$
}

Received: 26 May 2020 / Revised: 28 May 2020 / Accepted: 28 May 2020 / Published online: 18 June 2020

(C) The Japanese Society of Hypertension 2020

“...in the last few decades, we have managed to rein in famine, plague and war. Of course, these problems have not been solved, but they have been transferred from incomprehensible and uncontrollable forces of nature into manageable challenges..." was stated by Yuval Noah Harari in "Homo Deus: A Brief History of Tomorrow" [1]. However, even now or because of the current situation in which the world is tightly interconnected with advanced globalization, the newly emerged plague COVID-19 is a great menace threatening our entire existence, including our health, economics, education, and human relations. COVID-19 is still confronting us as a seemingly incomprehensible and uncontrollable disease. Until we make this disease a manageable issue, which I do believe that we can achieve, more time is needed for the creation of a sustainable new lifestyle standard with the challenge of COVID-19 (a "New Normal").

Noncommunicable diseases (NCDs), including hypertension, have come to be recognized as the main health problem since $~ 70 \%$ of deaths in the world (57 million deaths/ year) are attributed to NCDs. However, great concern has emerged that the pandemic of COVID-19, a communicable disease, will create another pandemic of NCDs [2]. This prediction could be plausible, considering our harsh and important Japanese experiences of the Great East Japan Earthquake that occurred on March 11, 2011 and the subsequent nuclear accident at the Fukushima Daiichi Nuclear Power Plant. Evacuation from the highly radioactive areas was performed. A survey of the evacuees reported that even

Hiroshi Itoh

hiito@keio.jp

1 Department of Endocrinology, Metabolism and Nephrology, Keio University School of Medicine, 35, Shinanomachi, Shinjuku-ku, Tokyo 160-8582, Japan two years after the disaster, their blood pressure remained significantly elevated by $\sim 4-5 \mathrm{mmHg}$ on average, and the incidence rates of obesity, diabetes and dyslipidemia, as well as hypertension, remained 1.2-1.5 times higher than those before the disaster [3]. The current situations in 2020 under the policy of social distancing and "stay at home" with self-restraint from going out are similar to those of the evacuation in 2011: sudden death of familiar persons, fear for death of ourselves, stresses produced due to family members being in the house all day long, feeling of detachment from friends and others, job loss and economic difficulties and so on.

2020 is the year of the 20th anniversary of the discovery of ACE 2 (angiotensin-converting enzyme 2) [4]. It is a mystery why this molecule, which cleaves angiotensin II, one of the central players of blood pressure and cardiovascular homeostasis, into angiotensin (1-7), is used for the entry of severe acute respiratory syndrome coronavirus 2 (SARS-CoV-2) into host target cells [5]. The reninangiotensin system is a relatively new endocrine system in phyletic evolution that produces high blood pressure to deliver adequate oxygen and nutrients throughout the body for survival.

ACE2 is expressed not only on pulmonary cells but also on intestinal and renal epithelial cells, cardiomyocytes and vascular endothelial cells [6]. Vascular endothelial cells are infected by SARS-CoV-2, resulting in the occurrence of systemic vasculitis and severe thromboembolism in relation to the "cytokine storm". Chromosome $\mathrm{X}$ harbors the gene coding for ACE-2, and the activity of transmembrane protease serine 2 (TMPRSS2), which facilitates the fusion of viral and cellular membranes, is androgen dependent [7]. These facts might be related to the sex preference of this disease [8]. Regulation of ACE2 expression by SARS-CoV-2 infection or by the administration of ACE inhibitors or angiotensin receptor blockers has been reported in in vitro 
cultured cells and in vivo animal models, and its clinical implication for COVID-19 has been argued [9].

Along with the observation that underlying cardiovascular diseases that are often caused by or complicated with hypertension are associated with an increased risk of severity of the disease [10], we should constantly attempt to discover and investigate the true picture of COVID-19 in relation to hypertension that has so far been delineated, that is, what is known and what is not yet known, to be well prepared for a possible pandemic of NCDs, including hypertension.

Our sincere scientific approach to cope with the reality of hypertension with COVID-19 would yield a New Normal hypertension medicine. This perspective opens up a new field of hypertension research to produce a concept of combined disease types of communicable and noncommunicable diseases, specific to each person's particular lifestyle and life environment. This new disease entity would include a new type of physical-mental stress-induced hypertension, a new type of vasculitis with hypertension, diseases evoked by lung-mediated organ miscommunication, or cardiovascular dysregulation produced by discordance between the human host and microorganisms. Facing the difficulty of frequent face-to-face examination of the patients performed in Old Normal medical practice, the New Normal of hypertension medicine also prompts us to cultivate the digital transformation of the medical practice of hypertension management to realize life-long care to naturally maintain a happy and healthy life, respecting the diversity of each person with hypertension. The establishment of a medical care system with constant connection to each person with hypertension by various IoT (Internet of Things) technologies and a medical advisory system to give personalized proper advice at the appropriate time according to the lifelog data of each person and the construction of a dynamic community remodeled with mutual dependence on each person's diverse quality of life are expected. Among them, the most important requirement is a "redesign" of the image of medical doctors being engaged in hypertension medicine to welcome the New Normal of hypertension medicine.

\section{Compliance with ethical standards}

Conflict of interest The author declares that they have no conflicts of interest.

Publisher's note Springer Nature remains neutral with regard to jurisdictional claims in published maps and institutional affiliations.

\section{References}

1. Harari YN. Homo deus: a brief history of tomorrow. London, UK: Vintage; 2017. p. 2.

2. Hall G, Laddu DR, Phillips SA, Lavie CJ, Arena R. A tale of two pandemics: How will COVID-19 and global trends in physical inactivity and sedentary behavior affect one another? Prog Cardiovasc Dis. 2020;S0033-0620:30077-3. https://doi.org/10.1016/ j.pcad.2020.04.005. Online ahead of print

3. Ohira T, Nakano H, Nagai M, Yumiya Y, Zhang W, Uemura M, et al. Changes in cardiovascular risk factors after the great east Japan earthquake. Asia Pac J Public Health. 2017;29:47S-55S.

4. Tipnis SR, Hooper NM, Hyde R, Karran E, Christie G, Turner AJ. A human homolog of angiotensin-converting enzyme. Cloning and functional expression as a captopril-insensitive carboxypeptidase. J Biol Chem. 2000;275:33238-43.

5. Hoffmann M, Kleine-Weber H, Schroeder S, Krüger N, Herrler T, Erichsen S, et al. SARS-CoV-2 cell entry depends on ACE2 and TMPRSS 2 and is blocked by a clinically proven protease inhibitor. Cell. 2020;181:271-80.

6. Hamming I, Timens W, Bulthuis ML, Lely AT, Navis G, van Goor H. Tissue distribution of ACE2 protein, the functional receptor for SARS coronavirus. A first step in understanding SARS pathogenesis. J Pathol. 2004;203:631-7.

7. Lin B, Ferguson C, White JT, Wang S, Vessella R, True LD, et al. Prostate-localized and androgen-regulated expression of the membrane-bound serine protease TMPRSS2. Cancer Res. 1999; 59:4180-4.

8. Wambier CG, Goren A, Vaño-Galván S, Ramos PM, Ossimetha A, Nau G, et al. Androgen sensitivity gateway to COVID-19 disease severity. Drug Dev Res. 2020. https://doi.org/10.1002/ddr.21688.

9. Kai H, Kai M. Interactions of coronaviruses with ACE2, angiotensin II, and RAS inhibitors-lessons from available evidence and insights into COVID-19. Hypertens Res. 2020. https://doi.org/10. 1038/s41440-020-0455-8.

10. Richardson S, Hirsch JS, Narasimhan M, Crawford JM, McGinn T, Davidson KW, et al. Presenting characteristics, comorbidities, and outcomes among 5700 patients hospitalized with COVID-19 in the New York city area. JAMA. 2020. https://doi.org/10.1001/ jama.2020.6775. 